\title{
Fair Criteria of Private Vocational School and Witnesses in the Perspective of Ushul Fiqh (Analysis Based on Istislahi and Ta'lili Reasoning)
}

\section{Jafar}

Islamic Family Law Department, IAIN Lhokseumawe, Indonesia

asyibriqi@yahoo.com

\begin{abstract}
The validity of a marriage, if it is equipped with several conditions, including a fair guardian and witnesses. This is as stated in several Hadith narrations, which clearly state that. However, in practice that is carried out by the community there is confusion regarding the fair requirements of guardians and witnesses. The proof is that all parents remain guardians in the process of their daughter's marriage and everyone can be witnesses in the marriage council. Among the scholars, there were disputes over this issue. The Ulama of the Hanafi School do not require fair guardians and witnesses in the marriage contract, even if a witness is allowed to be a man and two women. Meanwhile, for the other three schools, just guardians and witnesses in marriage are a condition for the validity of a marriage. It's just that there is a slight difference in this matter. The Ulama of the Maliki School, the two male witnesses who are just, may be presented after the marriage contract has taken place to testify that the couple is married. As for the Shafi'i School the requirements are rather strict because the fairness of guardians and witnesses must be clear inside and out. Meanwhile, according to the Hanbali School, it is a little light because the fairness of guardians and witnesses can be seen from the outside (mastur 'is). The condition for the fairness of guardians and witnesses based on istislahi theory of reasoning is to produce benefits in terms of hereditary purity. The purity of the offspring is only obtained through a marriage that is legal according to the rules of the Shari'a. The Sharia has established the validity of a marriage in between with a just guardian and witnesses. Based on the theory of ta'lili reasoning, the validity of the marriage contract is due to the existence of a just guardian and witnesses in the marriage.
\end{abstract}

\section{Keywords}

adil wali and marriage

witnesses; perspective of ushul fiqh, istislahi reasoning; Ta'lili reasoning

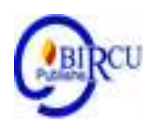

\section{Introduction}

Marriage is something sacred in Islam. Marriage requirements aim to maintain the purity of the offspring, so that the lineage becomes clear and there is no confusion. This goal can be achieved if a marriage procession takes place in a legal condition under the Shari'a. The validity of a marriage, if it is equipped with several conditions, including a fair guardian and witnesses. This is as stated in several Hadith narrations, which clearly state this, such as in the Hadith narrated by Ibn Hibban, Daruquthni and Baihaqi.

$$
\text { لاَ نِكَاحَ إِلاَّ بِوَلِيِّ وَشَاهِدَيْ عَدْلِ }
$$


A marriage without a guardian and two fair witnesses is not valid (Narrated by Ibn Hibban, Daruquthni and Baihaqi).

The term al-'is in Arabic and the term jurisprudence is very different from the meaning of the word fair or justice in Indonesian terms. Al-'adalah (a) in Arabic is often mentioned as:

Expression of a matter that is balanced between excess and deficiency.

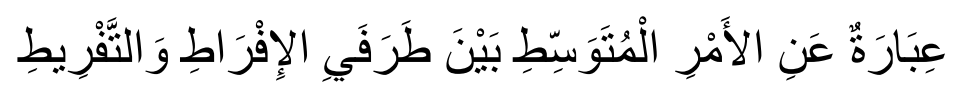

Meanwhile, the definition of a just person by the scholars is as follows:

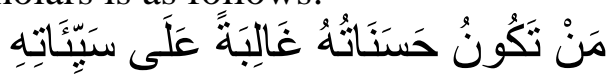

People whose goodness is more dominant than bad (Imam Alaudin, 1973).

There are also other definitions that are somewhat closer, for example:

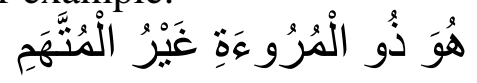

People who have muru'ah (authority) and are not accused (Imam Alaudin, 1973).

However, in practice that is carried out by the community there is confusion in terms of fair requirements guardians and witnesses. The marriage guardian is a pillar that must be fulfilled for the prospective bride who acts to marry her (Compilation of Islamic Law in Imran, 2020). The proof is that all parents remain guardians in the process of their daughter's marriage and everyone can be witnesses in the marriage council. In fact, they feel proud if they can marry off their daughters directly, without being represented by other people and also feel proud to be appointed as witnesses in a wedding procession (Imam Alaudin, 1973).

Of all the problems above, this paper would like to focus on the study of fair guardian and marriage witnesses using the analysis theory of Ushul Fiqh. Then look for differences of opinion among ulama and the factors that cause differences in views among them. Then it examines the fair criteria of guardians and witnesses in marriage based on the theory of istislahi and ta'lili reasoning.

\section{Review of Literatures}

\subsection{Guardians and Witnesses and Their Problems}

The word "wali" according to the language comes from Arabic, namely al-Wali with the plural form Auliyaa which means lover, brother, or helper. Meanwhile, according to the term, the word "guardian" means a person who according to law (religion, custom) is entrusted with taking care of the orphan's obligations before the child grows up; the party who represented the bride at the time of marriage (that is, the one who entered into the marriage contract with the groom). The guardian in the marriage is the one on which the validity of the marriage contract lies, so the marriage is not valid without the existence (guardian).

\section{a. Types of Guardians and Their Order}

According to M. Idris Ramulyo (1999) there are 3 types of guardians in marriage, namely: 


\section{Trustee of the Nasab}

Wali nasab are people who consist of the family of the prospective bride and have the right to become a guardian. In determining the guardian of the lineage there are differences of opinion among the scholars. This difference is caused by the absence of clear instructions from the prophet, while the Koran does not discuss at all who has the right to become a guardian. Jumhur ulama divide it into two groups: First: a close guardian (wali qarib), namely the father and if there is no father, he moves to the grandfather. Both have absolute power over the daughter he will marry. Second: distant guardians (wali ab'ad), namely guardians in the line of relatives apart from father and grandfather, also apart from children and grandchildren. The guardians of the ab'ad are as follows:

1) Natural brother, if not available, move to;

2) Parents, if not available, move to;

3) Children of biological brothers, if not available, move to;

4) If a brother is not present, he will move to;

5) Uncle biological, if not available, move to;

6) Uncle, if not available, move to;

7) Uncle's child, if not available, move to;

8) Uncle's child;

9) Other relative heirs if any.

\section{Guardian Judge}

Guardian judge is a person appointed by the government to act as guardian in a marriage. The guardian of the judge can replace the guardian of lineage if the prospective bride does not have a guardian of lineage at all.

1) Walinya mafqud, meaning that its existence is uncertain.

2) The guardian himself will become the groom, while an equal guardian does not exist.

3) The guardian is in a place that is as far as masaful qasri (as far as the journey that allows qashar prayer) which is $92.5 \mathrm{~km}$.

4) The guardian is in a prison or detention that cannot be found.

5) The guardian is performing the Hajj or Umrah pilgrimage.

6) Adultery child (he only festered with his mother).

7) The guardian is crazy or wicked.

In accordance with the Regulation of the Minister of Religion Number 2 of 1987, the one appointed by the Minister of Religion as the guardian of the judge is the District KUA.

\section{Wali Muhakkam}

A wali muhakkam is someone who is appointed by both husband and wife candidates to act as a guardian in their marriage contract. People who can be appointed as wali muhakkam are other people who are respected, respected, the extent of their jurisprudence, especially about hypocrisy, have broad views, are just, Islam and men.

\section{b. Witness is Married}

Witness according to language means people who see or know something for themselves (incident). Meanwhile, according to the term is a person who provides information and is accountable for what it is (Djaaman, 1993).

Rasulullah himself in various Hadith narrations even though with different editors stated the urgency of a marriage witness, as stated in a Hadith:

$$
\text { لاَ نِكَاحَ إِلاَ بَوَلِيِّ وَشَاهِدَيْ عَدْلٍ }
$$


"A marriage contract is not valid unless (attended by) a guardian and two fair witnesses'.

Even in another Hadith narrated by Turmudzi it is stated that prostitutes (al-baghaya) are women who marry themselves without witnesses (bayyinah).

According to Malikiyah, witnesses are not required to be present at the time of the contract, but witnesses will be required to be present after the contract before the husband interferes with his wife. In fact, Malikiyah prioritizes i'lan marriage rather than testimony itself, because in i'lan there is already accumulated testimony. However, they still presented two witnesses as a form of their practice of this Hadith. This was based on the view of Malikiyah, who really put forward the practice of Medina experts who at that time practiced the hadiths related to i'lan.

In the statutory regulations, namely Article 1 (26) of the Criminal Code states the definition of a witness, namely: "A witness is a person who can provide information for the sake of a case about a case that he has heard himself, he has seen and experienced himself by stating the reasons for his knowledge".

\section{c. The View of the Scholars of the Mazhab about the Fairness of Witnesses and Marriage Guardians}

Fuqaha`Shafi'iyyah, like Ibn Hajar al-Haitami in his book Tuhfah al-Muhtaj, Imam Ramli al-Anshary in his book Nihayah al-Muhtaj, Sulaiman bin 'Umar bin Muhammad alBujairimi in his book Hasyiah Bujairimi, Imam Muhammad Khatib al-Syarbini in Mughni alMuhtaj's book, Sayid Bakri in his book I'anah al-Talibin, and other scholars in the Shafi'i School all have the same opinion and there is no difference in views between them regarding the requirements of a just guardian and witness when a marriage procession is carried out. . As for the fairness of the witness, according to them, was not committing a major sin or not having more minor sins than obedience, not doing anything that could undermine his dignity. Whereas the guardian is required to be ungodly, This means that if a person who is going to act as a guardian of marriage ever commits a grave sin then he repents, he can immediately become a guardian of marriage. As for witnesses, if a wicked person repents, then he must wait a year, after which he may become a marriage witness.

As for according to fuqaha 'Hanafiyah like Imam al-Sarakhsi in his book al-Mabsut, Ibn 'Abidin in his book Radd al-Muhtar' ala al-Durr al-Mukhtar, Ibn Nujam al-Misri in his book al-Bahr al-Ra'iq Syarh Kanz al-Daqa'iq, Imam al-Kasani in his book Bada'i 'al-Sana'i',and others are of the opinion that witnesses and guardians are not required to be fair. According to them, the important thing is to have a guardian and two witnesses. Two witnesses may also be two men or one man and one woman.

\section{Discussion}

\subsection{Opinions of Inter-School Ulama Regarding Requirements for Guardians and Witnesses in Marriage}

In this sub-discussion the author will systematically discuss the views of the ulama (fuqah $a^{\prime}$ ) the school regarding the requirements of guardians and witnesses in marriage which is the focus of discussion in this paper. As for the schools of thought, the author is referring to the Schools Hanafi, School of Maliki, and School of Syafi 'i, and the School Hanbali.

\section{a. Hanafi School}

Of the many books (books) of fiqh references in the School Hanafi the author only takes two works as a guide in examining the problems of guardians and witnesses in marriage here, namely al-Mabsut works of Imam al-Sarakhsi and al-Ikhtiyar li Ta'lil al-Mukhtar creation 'Abd Allah al-Musili. The reason the author chose these two works was because they were 
both the greatest and most famous works in the school and they were easy for the author to obtain.

\section{In al-Mabsut}

Imam al-Sarakhsi, one of the scholars who followed the School Hanafi in his book alMabsut explained that guardian is a legal condition of marriage for women who are still girls. As for women who are widows may marry themselves. Apart from that, there are additional requirements here, namely that there must be two witnesses. This extra requirement indicates the fact that there is danger to the budh '(vagina). Therefore, two witnesses are needed in the event of a conflict later in navigating the married life between the husband and wife. Then every person who deserves to make a transaction (contract) for himself, then the marriage contract is valid with his testimony. Every person who is eligible to become a guardian of marriage, then he or she deserves to be a witness in the marriage. On the basis of this information, every marriage is valid with the testimony of two wicked people. Meanwhile, according to Imam Syafi'i it is invalid because he is guided by the Hadith: "The marriage contract is not valid, but with a guardian and two fair witnesses". In our opinion, the mention of fair conditions in the Hadith and not mentioned in the other narrations that we have mentioned, we practice both simultaneously. But we reject the mention of fair conditions in the places mentioned, so what is meant is fair in any case, namely fair in terms of belief (creed) (Syams, 2000).

According to Imam Shafi'i, it is not valid. Because the testimony of a man and two women is only accepted in the matter of suing for property and related to it. The reason is because in carrying out transactions related to these things occur a lot among humans, and there would be trouble if only two men were accepted as witnesses. Therefore, being accepted by two women as a substitute for a male witness is an emergency condition in this case, and there is no emergency in the marriage contract and divorce and it has nothing to do with property. Also, these transactions are not often carried out by humans, so they are equated with penalties in a criminal act and due to the fact that women are not accepted as witnesses.

\section{In al-Ikhtiyar li Ta'lil al-Mukhtar}

'Abd Allah al-MusiliIn his book, it explains that, in addition to a guardian as a condition for marrying a woman, a witness is also required so that the marriage contract is valid. The witnesses were two men or a man and two women. These witnesses are required to be independent and Islamic, but not fair. The witnesses are a condition for the validity of marriage because it is emphasized in the Hadith: "Marriage is not valid, but there are witnesses".

As for the characteristics of a witness, it is everyone who is allowed to hand over a marriage for himself, then a marriage contract is valid because of his testimony. Because between the two have a correlation as a condition for the validity of a marriage contract. Marriage witnesses are also required to be free, intelligent, and mature people because slaves, crazy people, and children are not considered competent as marriage witnesses nor are they allowed to hand over marriage for themselves.

So, based on the two fiqh references of the Hanafi School above, it is clear that just guardians and witnesses are not a requirement for the validity of the marriage contract. The important thing is to be Muslim and not to lie when his testimony is needed one day if there is a dispute about the marriage. Witnesses may also be a man and two women, as is the testimony in disputes related to property. 


\section{b. The Maliki School}

Of the many books (books) that can be used as references from the M Schoolaliki, the researcher only took two pieces in discussing the problems of guardians and witnesses in marriage here, namely al-Mudawwanat al-Kubr. $a$ works of Imam Malik itself and Mawahib al-Jalil li Syarh Mukhtasar al-Khalil by Shams al-Din al-Tarablearyi. The author chose these two works because they were well known in the school and easy for the author to get them.

\section{In al-Mudawwanat al-Kubra}

MaLik bin Anas in his book explains that, real slaves and mukatab (slaves who have made an agreement with their master for independence if they are able to pay a certain amount of money within a predetermined time) may not marry (become guardians of marriage) their daughters, sisters. , and his mother. A Christian wali is also prohibited from marrying off his Muslim daughter. Likewise, a Muslim wali may not marry his Christian daughter to a Muslim husband, if the woman is a zimmi expert (has paid soul tax to the state). But a Christian wali may marry his Christian daughter to a Muslim husband. So, slaves in any status and Christians are not allowed to marry off their daughters who are still girls even with their consent. The reason is because they do not meet the requirements to perform the marriage contract. An apostate is not allowed to marry off his daughter who is still a girl, he cannot even eat his slaughter A wali who is zimmi alone cannot marry his Muslim daughter, let alone an apostate saint. Because an apostate does not become the heir of his Muslim family and other people, it means that his guardianship has been cut off because of the apostasy.

If someone marries his daughter without witnesses, then the marriage must be terminated (fasakh). But if a person confesses that he married his daughter to a man without witnesses, then he should testify to two male witnesses for the next period. This applies if the two of them have not yet had a husband and wife relationship. Even if they have done so, then the relationship is forbidden (haram). Then, previous marriages without witnesses are still valid by being witnessed to the two male witnesses for the future.

\section{In Mawahib al-Jalil li Syarh Mukhtasar al-Khalil}

Shams al-Din al-Tarablearyi In his book, it is stated that when the marriage contract is carried out, two fair people must be witnessed, apart from the guardian. What is understood outwardly here is that fair conditions are needed when bearing his testimony in the marriage contract process. A wicked person is a person whose speech is not accepted, both historically and by testimony, and that is the consent of the scholars besides Abu Hanifah's statement which states that the marriage contract is valid with the testimony of two wicked witnesses. According to the rules, two witnesses are required in the marriage, this is in contrast to Abu Hanifah (Shams, 2003).

From the discussion of the two references to the Maliki School of jurisprudence above, it appears that just guardians and witnesses are a valid condition of a marriage contract process. It's just that the problem of witnesses, can be witnessed after the marriage contract occurs. This means that the two witnesses do not have to be present in the marriage contract. After the marriage contract, the guardian may present two fair male witnesses to testify that both (male and female) have been married.

\section{c. Shafi'i School}

In reviewing guardian and witness issues in marriage according to the School of Syafi'i, author also take only two references as a reference, namely al-Hawi al-Kabirby al-Mawardi and al-Majmu'Syarh al-Muhadhdhab works of Imam al-Nawawi. The reason the authors 
chose these works was because they were the biggest and most famous and easy for the writers to get.

\section{In al-Hawi al-Kabir}

Al-Mawardiin the book it states that the witness at the marriage contract is obligatory. When the legal witness is obliged to the marriage contract, then he becomes a condition for the validity of the marriage. Therefore, a marriage contract is not valid without the presence of two male witnesses, or one male witness and two female witnesses. When both witnesses must be men, both must be fair. The terms of the fairness of the two witnesses were understood from QS. al-Talaq: regarding the witness to divorce and reconciliation recommended by Allah. In the verse clearly states "and witness the divorce and refer it to two just men". So, in the case of divorce and reconciliation, witnesses are not required but are required to be fair, especially in the case of a marriage contract where two witnesses are clearly legally obligated (Abu Al-Hasan, 1974).

Then the guardian is also required to be rusyd (good religion / fairness and wealth), so the marriage contract is not valid if the guardian is ungodly. If the person who has the right to become a guardian is found to be ungodly, then the right of the guardian will be transferred to another guardian. But if he wants to repent, then the right of guardian returns to him. If during his wicked time he represents someone else to marry off his daughter, the wakalah (surrender of the guardian's right) is void. Since everyone who is wicked has lost power from him, he has no right to represent him (Abu Al-Hasan, 1974).

\section{In al-Majmu'Syarh al-Muhadhdhab}

Imam al-NawawiIn his book, it explains that, children, crazy people, and slaves cannot become guardians of marriage because they do not have (cannot do) a contract for themselves, so they cannot be owned (cannot be done) for others. The guardian also must not be a wicked person, based on Imam Shafi'i's verse. The reason is, because the guardian is the right to control (territory), then the wicked do not have this right. This is the same as the right of control relating to property (Abu Al-Hasan, 1974).

Said Imam Shafi'i in al-Buwayti, a wali must be murshid (good at safeguarding his religion and wealth). Meanwhile, in another place, he emphasized that female guardians who are kafir are infidels. From this statement it can be understood that it is permissible to be the guardian of the wicked. Among Imam Shafi'i's own students there were differences of opinion regarding wicked people, whether or not they could be guardians of marriage?

Marriage is not valid unless attended by two witnesses. According to Abu Tsur, legal marriage without witnesses being present, because marriage is a contract, it is legal without witnesses being present, just like a sale and purchase contract. This opinion is wrong because based on the hadith narrated by Aisyah that the Prophet said: "Every marriage that is not attended by four people, then the marriage is adultery. The four people are the groom, the guardian, and the two witnesses". This is different from the sale and purchase contract because in the sale and purchase agreement what is meant is property. Meanwhile, what is meant by the marriage contract is to have fun between a man and a woman, and also to get offspring. Therefore, to obtain both types, it must be in a sure and convincing way (ikhtiyat).

From the two fiqh references to the Shafi'i School above, it can be understood that guardians and witnesses must be just inside and out (physically and mentally). If on the surface it looks fair, then it cannot be a witness for marriage. This is based on a strong opinion in the Shafi'i School. If a guardian is wicked and wants to repent, he can immediately become a guardian of marriage because the condition is not wicked. By repenting means that a person is no longer wicked. But if a wicked witness must first repent and a year later he can 
only become a marriage witness because the conditions must be fair. It is only said that in a year, someone has never committed a major sin.

\section{d. Hanbali School}

From a number of books (books) that can be used as references in the School HanbaliThe author also only took two pieces of fiqh works as a source of guidance in discussing the requirements of guardians and witnesses in marriage. The two works areal-'Uddah Syarh al'Umdah the work of al-Maqdisi and al-Mabda'Syarh al-Maqna'by Burhan al-Din. The author reasoned that these works are not only well known (well-known) in the SchoolsHanbali, also easy for writers to get.

\section{In al-'Uddah Syarh al-'Umdah}

Abu Yourhammad Baha'uddin al-Maqdisiln his book, it explains that, to be a marriage witness, several conditions are required; First, it is fair because it is based on the words of the Holy Prophet: "The marriage contract is not valid unless there is a guardian and two fair witnesses". Second, two men because based on the narration of Abu 'Ubaydah from al-Zuhri in the book al-Amwal (which discusses property), he said: "It is the sunnah that women's testimony is not accepted on matters relating to criminal punishment. (hudud), marriage, and divorce ". Third, baligh because the children were not accepted by the testimony. Fourth, reason because crazy people and children are not considered competent in terms of testimony (Abd al-Rahman, 2005).

\section{In al-Mabda'Syarh al-Maqna'}

As for fairness is not required according to a history. It is an understanding that was born from the talk of al-Kharqi. According to him, a wicked guardian may marry a woman. Because a wicked person may marry himself, let alone marry someone else. As for the second opinion which is supported by the nas, fair guardian is a condition of validity of marriage. This opinion was chosen and supported by Ibn Abi Musa, Ibn Hamid, al-Qadhi and his friends. This opinion is supported by a Hadith: "The marriage contract is not valid unless there is a guardian who is a nursyid (good at safeguarding his religion and property)". But based on this opinion, it is permissible to be the guardian of a person whose fairness is hidden (seen from the outset / outwardly fair). This opinion is supported by a Hadith: "The marriage contract is not valid unless there is a guardian who is a nursyid (good at safeguarding his religion and property)". But based on this opinion, it is permissible to be the guardian of a person whose fairness is hidden (seen from the outset / outwardly fair) (Ibrahim, 2003).

The next condition is that both of them must be baligh and sensible, so that the testimony of children and crazy people is not accepted because both are considered not experts (incompetent) in terms of testimony. DHe also indicated that the two witnesses were Muslim, that infidels were not allowed to witness the marriage of Muslims. Deaf people and mute people are also not allowed to be witnesses because deaf people did not hear when the contract was made, so he could not possibly witness the contract. Likewise, a mute person, it is impossible for him to give his testimony information when needed at one point in time. Therefore, the presence of both of them seemed non-existent.

Based on the two Hanbali School fiqh references above, it can be understood that guardians and witnesses are required to be fair. It's just that there is a little relief on fairness, that is, it is permissible to cover one's fairness. This means that on the outside it is considered fair to be a guardian and a marriage witness. Meanwhile, the interior does not need to be examined because it is considered difficult because there are so many marriage contracts in remote areas of the village and in the midst of crowds. 


\subsection{Fair Criteria for Guardians and Witnesses in Marriage Based on Istislahi}

\section{Reasoning Theory and Ta'lili}

a. Fair Criteria for Guardians and Witnesses According to Isti's Reasoning Theoryslahi

The meaning of syara '(maqUSid al-syar'iyyah) towards creatures there are five, namely maintaining their religion, soul, mind, descent, and property. Everything in it contains maintenance of the five points, then it is called maslahAh. Whereas anything that can eliminate these points is called mafsadah, rejecting it is maslahAh. Maintaining the five points above ranges from levelsdaruriyat. This is the most powerful dignity (rank) in maslahAh.. The decision obliged the punishment for adultery because with it the purity of the offspring would be maintained. The decision requires punishment for robbers and thieves because with it the property which is the source of life will be preserved. All of these are primary needs (daruriyat) Humans in living their life and the law is haram to eliminate the five points mentioned earlier (Al-Imam, 2008).

\section{b. Fair Criteria for Guardians and Witnesses According to Ta'l Reasoning Theoryili}

Ta'l theory of reasoningiliyahis a reasoning that tries to reveal what is the background of a legal provision in the Koran and Hadith, or what is the 'illat of an act. In the theory of reasoning ta'liliyah there are provisions that say 'illatnya, some are hinted at and some are not mentioned' illat at all (Yourhammad, 1984).

As for the fair requirements of guardians and witnesses in marriage which are stipulated through the arguments of the Hadith, it is not clearly stated that the syllable is, but can be found after being traced through various existing Hadith narrations and their meaning. It turns out that his' illat is found hintingly in the arguments of the Hadith itself.

The discovery of 'illat among usuliyun is generally done for the needs of pengqiyasan. Therefore, the discussion of 'illat is focused on' illat al-qiyasiyyah. In this regard, al-Ghazali of the opinion that every law is syara' which may be dita'lil, then it may be diqiyas. While in the determination of syara 'law, sometimes al-Syari ' stipulating law alone, or stipulating law at the same time determining certain characteristics along with the law as the reason for the obligation of the law.

Islamic Sharia is enforced on strengths and prioritizes morals or ethics (moralsaq), honor (self-respect), and the offspring of being mixed up. Humans are obliged to defeat their desires (biological desires) in a lawful way, namely a legal marriage, as is required when a person is physically and mentally able to marry, so that he does not cause slander or does not endure something he is not able to (Abd Al-Qadir, 1997). From this investigation, it can be concluded that 'illat is required to be fair guardians and witnesses in marriage because of marriage.

\section{Conclusion}

After examining various kinds of written data sources, the researchers concluded the following:

1. The issue of fairness of guardians and witnesses in marriage is a disputed issue among scholars between schools of thought. The Ulama of the Hanafi School do not require fair guardians and witnesses in the marriage contract, even if a witness is allowed to be a man and two women. Meanwhile, for the other three schools, just guardians and witnesses in marriage are a condition for the validity of a marriage. It's just that there is a slight difference in this matter. The Ulama of the Maliki School, the two male witnesses who are just, may be presented after the marriage contract has taken place to testify that the couple is married. Before the two witnesses were presented, the validity of the marriage contract was still hanging. This means that the couple is not lawful to 
have a relationship like husband and wife. As for the Shafi'i School the requirements are rather strict because the fairness of guardians and witnesses must be clear inside and out.

2. The condition for the fairness of guardians and witnesses based on the theory of istislahi reasoning is to produce benefits in terms of hereditary purity. The purity of the offspring is only obtained through marriage which is legal according to the rules of the Sharia The Sharia has established the validity of a marriage in between with a just guardian and witnesses. Based on the ta'lili reasoning theory, the validity of the marriage contract is due to the existence of a fair guardian and witnesses in the marriage.

\section{References}

'Abd al-Rahman bin Ibrahim bin Ahmad Abu Muhammad Baha'uddin al-Maqdisi, al-'Uddah Syarh al-'Umdah, Juz II, Cet. 2, Beirut: Dar al-Kutub al-'Ilmiyah, 2005.

'Abd Allah bin Mahmud bin Mawdud al-Musili al-Hanafi, al-Ikhtiyar li Ta'lil al-Mukhtar, cet. III, juz III, Beirut: Dar al-Kutub al-Ilmiyah, 2005.

'Abd al-Qadir 'Awdah, al-Tasyri' al-Jina'i al-Islami Muqaranan bi al-Qanun al-Wad'i, juz II, Beirut: Mu'assasah al-Risalah, 1997.

Abdur Rahman Ghozali, Fiqh Munakahat, Ed. I, Cet. III, Jakarta: Kencana, 2008.

Abu al-Hasan 'Ali bin Muhammad bin Habib al-Basri al-Baghdadi al-Mawardi, Al-Hawi alKabir, Juz XIII, Cet. I, Beirut: Dar al-Kutub al-'Ilmiyah, 1994.

Al-Buhuti, Kasysyaf al-Qinna', jld. VI, Beirut: Dar al-Kutub al-'Ilmiyah, t.t.

Amir Syarifuddin, Hukum Perkawinan Islam di Indonesia; antara Fiqh Munakahat dan Undang-undang Perkawinan, Cet. III, Jakarta: Kencana, 2009.

Djamaan Nur, Fiqih Munakahat, Semarang: Dina Utama Semarang, 1993.

Ibrahim bin Muhammad bin 'Abdullah bin Muhammad Ibn Muflih Abu Ishaq Burhan al-Din, al-Mabda' Syarh al-Maqna', juz VII, Riyad: Dar 'Ulum al-Kutub, 2003.

Ibrahim bin Musa bin Muhammad al-Syatibi, al-Muwafaqat fi Ushul al-Syari`ah, Kairo: Maktabah Tawfiqiyyah, t. t.

Imam Abu Hamid Muhammad bin Muhammad al-Ghazali, al-Mustasfa min 'Ilmi al-Ushul, Cet. I, Beirut: Dar al-Kutub al-'Ilmiyah, 2008.

Imam Abu Zakariyya Muhyi al-Din Yahya bin Syarf al-Nawawi, al-Majmu' Syarh alMuhazzab, Juz XVI, Beirut: Dar al-Fikr, t.t.

Imam Alaudin Abi al-Hasan Ali bin Kholil al-Tari Ablasi al-Hanafi, Mu'inul Hukkam, cet. II, Kairo: Mustafa Bab al-Halbi wa Auladah, 1973.

Imam Suprayogo dan Tobroni, Metodologi Penelitian Sosial-Agama, Bandung: Rosda Karya, 2003.

Imran, et al. (2019). Tawkil Traditions in the Implementation of Marriage Contract in Aceh, Indonesia. Budapest International Research and Critics Institute-Journal (BIRCIJournal) Vol 2 (3): 210-218.

Lexy J. Moleong, Metodologi Penelitian Kualitatif, Bandung: Rosda Karya, 2005.

M. Idris Ramulyo, Hukum Perkawinan Islam, cet. 2, Jakarta: Bumi Aksara, 1999.

Malik bin Anas bin Malik bin 'Umar al-Asbuhi al-Madani, al-Mudawwanat al-Kubra, juz II, Beirut: Dar al-Kutub al-'Ilmiyah, t.t.

Moh. Rifa'i, Ilmu Fiqih Islam Lengkap, Semarang: Toha Putra, 1978.

Muhammad Salam Madkur, al-Ijtihad al-Islam fi al-Tasyri‘ al-Islami, Ttp: Dar al-Nahİah 'Arabiyah, 1984.

Rahmat Hakim, Hukum Perkawinan Islam, Cet. I, Bandung: Pustaka Setia, 2000.

Soerjono Soekanto, Pengantar Penelitian Hukum, Jakarta: UI-Press, 1986. 
Syams al-Din Abi 'Abd Al-lah Muhammad bin Muhammad bin 'Abd al-Rahman alTarabilisi al-Maghribi, Mawahib al-Jalil li Syarh Mukhtasar al-Khalil, Juz V, Beirut: Dar 'Ulum al-Kutub, 2003.

Syams al-Din Abi Bakr Muhammad bin Abi Sahl al-Sarakhsi, al-Mabsut, Juz V, Cet. I, Beirut: Dar al-Fikr, 2000. 